\title{
Subnormothermic ex vivo lung perfusion attenuates ischemia reperfusion injury from donation after circulatory death donors
}

\author{
Stephan Arni $\odot^{\ddagger}$, Tatsuo Maeyashiki ${ }^{\ddagger}$, Isabelle Opitz $\odot$, Ilhan Inci* \\ Department of Thoracic Surgery, University Hospital Zurich, Zurich, Switzerland \\ ¥ S.A and T.M. are joint first co-authors. \\ * Ilhan.inci@usz.ch
}

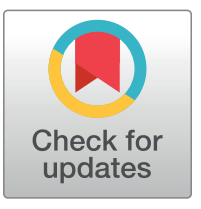

\section{f OPEN ACCESS}

Citation: Arni S, Maeyashiki T, Opitz I, Inci I (2021) Subnormothermic ex vivo lung perfusion attenuates ischemia reperfusion injury from donation after circulatory death donors. PLOS ONE 16(8): e0255155. https://doi.org/10.1371/journal. pone. 0255155

Editor: Edward J. Lesnefsky, Virginia Commonwealth University, UNITED STATES

Received: January 7, 2021

Accepted: July 10, 2021

Published: August 2, 2021

Copyright: @ 2021 Arni et al. This is an open access article distributed under the terms of the Creative Commons Attribution License, which permits unrestricted use, distribution, and reproduction in any medium, provided the original author and source are credited.

Data Availability Statement: All relevant data are within the manuscript and its Supporting Information files are available from the Dryad database (accession number https://datadryad.org/ stash/share/

8qGUl1W6S5h3aba4t5HVXQTdmneQ2vxnBSBmbB37A0).

Funding: Financial disclosure statement. The authors would like to thank the following: The Swiss Lung Foundation, the Fondation A.P. Naef

\section{Abstract}

Use of normothermic ex vivo lung perfusion (EVLP) was adopted in clinical practice to assess the quality of marginal donor lungs. Subnormothermic perfusion temperatures are in use among other solid organs to improve biochemical, clinical and immunological parameters. In a rat EVLP model of donation after circulatory death (DCD) lung donors, we tested the effect of four subnormothermic EVLP temperatures that could further improve organ preservation. Warm ischemic time was of 2 hours. EVLP time was of 4 hours. Lung physiological data were recorded and metabolic parameters were assessed. Lung oxygenation at $21^{\circ} \mathrm{C}$ and $24^{\circ} \mathrm{C}$ were significantly improved whereas pulmonary vascular resistance and edema formation at $21^{\circ} \mathrm{C}$ EVLP were significantly worsened when compared to $37^{\circ} \mathrm{C}$ EVLP. The perfusate concentrations of potassium ions and lactate exiting the lungs with $28^{\circ} \mathrm{C}$ EVLP were significantly lower whereas sodium and chlorine ions with $32^{\circ} \mathrm{C}$ EVLP were significantly higher when compared to $37^{\circ} \mathrm{C}$ EVLP. Also compared to $37^{\circ} \mathrm{C}$ EVLP, the proinflammatory chemokines MIP2, MIP-1 $\alpha$, GRO- $\alpha$, the cytokine IL- 6 were significantly lower with $21^{\circ} \mathrm{C}, 24^{\circ} \mathrm{C}$ and $28^{\circ} \mathrm{C} \mathrm{EVLP}$, the IL-18 was significantly lower but only with $21^{\circ} \mathrm{C}$ EVLP and IL-1 $\beta$ was significantly lower at $21^{\circ} \mathrm{C}$ and $24^{\circ} \mathrm{C}$ EVLP. Compared to the $37^{\circ} \mathrm{C} E V L P$, the lung tissue ATP content after $21^{\circ} \mathrm{C}, 24^{\circ} \mathrm{C}$ and $28^{\circ} \mathrm{C}$ EVLP were significantly higher, the carbonylated protein content after $28^{\circ} \mathrm{C}$ EVLP was significantly lower and we measured significantly higher myeloperoxidase activities in lung tissues with $21^{\circ} \mathrm{C}, 24^{\circ} \mathrm{C}$ and $32^{\circ} \mathrm{C}$. The $28^{\circ} \mathrm{C}$ EVLP demonstrated acceptable physiological variables, significantly higher lung tissue ATP content and decreased tissue carbonylated proteins with reduced release of pro-inflammatory cytokines. In conclusion, the $28^{\circ} \mathrm{C}$ EVLP is a non inferior setting in comparison to the clinically approved $37^{\circ} \mathrm{C}$ EVLP and significantly improve biochemical, clinical and immunological parameters and may reduce I/R injuries of DCD lung donors.

\section{Introduction}

Lung transplantation is the accepted final treatment option for end stage lung diseases, once all possible conservative treatments have been exhausted. With more than three decades of success stories in the field, the waiting list mortality is still an issue among lung transplant 
and the Jubiläumsstiftung der Lungen Liga Graubünden.

Competing interests: We presented part of this work as a poster (Subnormothermic ex-vivo lung perfusion attenuates ischemia reperfusion injury from donation after circulatory death donors) at the 2019 ISHLT annual Meeting in Orlando, FL, USA. The other authors declare that they have no conflict of interest. This does not alter our adherence to PLOS ONE policies on sharing data and materials.

Abbreviations: Cdyn, Dynamic lung compliance; $\mathrm{DCD}$, Donation after circulatory death; EVLP, Ex vivo lung perfusion; $\mathrm{FiO}_{2}$, Fraction of inspired oxygen; I/R, Ischemia-reperfusion; PAP, Pulmonary arterial pressure; PEEP, Positive endexpiratory pressure; MPO, Myeloperoxidase; PVR, Pulmonary vascular resistance; TUNEL, Terminal deoxynucleotidyl transferase dUTP nick end labeling. candidates [1]. Novel strategies are implemented to overcome this shortage, such as living donor lobar lung transplantation, application of extended criteria (marginal) donor lungs, donation after circulatory death (DCD) donors [2]. However, in the modern era and even with an increasing number of lung transplantation being performed around the world, the demand for donor lungs is still outpacing scarcity of suitable lung donor organ [1].

Ex vivo lung perfusion (EVLP) was developed to increase lung utilization by re-evaluating, treating, and repairing questionable donor lungs before transplantation [3]. Normothermic EVLP is adopted in clinical practice to assess the quality of marginal donor lungs [4]. However, future protocols will require advances to perform longer machine perfusion time for the purpose of efficiently repair questionable lungs [5]. Decreasing the ex vivo perfusate temperature has been already used in clinical practice in other solid organs such as liver [6-10] and kidney [11] and has been shown to reduce tissue metabolism and effectively protect from ischemiareperfusion (I/R) injury $[7,11,12]$. Nevertheless, few investigators have studied which perfusion temperature might be useful during EVLP [12-15].

The main goal of normothermic machine perfusion is to optimize graft preservation by mimicking physiological conditions and allows the continuous elimination of toxic products from the cellular milieu and actively restores ATP and glycogen reserves. Normothermic perfusion enables organ viability assessment before transplantation, prolonged preservation, and resuscitation from injuries. In this study, we investigated the effect of perfusion temperature as one of the key factor for graft improvement. Nonetheless, it is still unknown which condition is physiologically advantageous for DCD lung organ preservation among hypothermic lung perfusion $\left(4-10^{\circ} \mathrm{C},[12]\right)$, subnormothermic lung perfusion $\left(20-33^{\circ} \mathrm{C}[13]\right)$, or normothermic lung perfusion $\left(37^{\circ} \mathrm{C}\right)$. In this study, we demonstrated the physiological as well as biochemical, clinical and immunological parameter improvements to clarify the cytoprotective benefits of reduced cellular metabolism under subnormothermic lung perfusion temperatures that could further improve organ preservation in DCD lung donors.

\section{Materials and methods}

\section{Animals}

Protocols of animal experiments for this study were approved by the Veterinary Office of the Kanton Zürich, Switzerland (reference ZH228/16). Pathogen-free male Sprague Dawley rats (Janvier Labs, France) of 280-360g weight were bred in specific pathogen-free area and treated according to the "Guide for the Care and Use of Laboratory Animals: Eighth Edition" [16].

\section{Surgical techniques for donation after circulatory death donor lung and EVLP model}

The rats were anesthetized with isoflurane and underwent tracheotomy and mechanical ventilation with a rodent ventilator (Harvard Apparatus, Inc., Model Ventelite, Germany). We selected a tidal volume of $10 \mathrm{~mL} / \mathrm{kg}$ and a respiratory rate of 60 breaths $/$ min with a positive end-expiratory pressure (PEEP) set at $3 \mathrm{cmH}_{2} \mathrm{O}$. Following laparotomy and sternotomy we injected 300 IU heparin into the inferior vena cava and sacrificed the rats by clamping the ascending aorta. The pulmonary artery and the left atrium perfusion cannulae (Hugo Sachs, Hugstetten, Germany) were then inserted. We set a perfusion pressure of $20 \mathrm{cmH}_{2} \mathrm{O}$ and flushed both lungs with $20 \mathrm{~mL}$ of cold low-potassium dextran solution (Perfadex plus, Xvivo Perfusion, Göteborg, Sweden) through the pulmonary artery cannula. The Perfadex plus solution was designated for the storage of lung transplants. At $4^{\circ} \mathrm{C}$, and out from a sealed Perfadex plus bag the $\mathrm{pH}$ was of 7.4 and the oxygen tension (pO2) was of $35.19 \mathrm{kPa}$. Perfadex plus 
contain $50 \mathrm{~g} / \mathrm{l}$ of Dextran $40,6 \mathrm{mmol} / \mathrm{l}$ potassium, $138 \mathrm{mmol} / \mathrm{l}$ sodium, $0.8 \mathrm{mmol} / \mathrm{l} \mathrm{magne-}$ sium, $132 \mathrm{mmol} / \mathrm{l}$ chloride, $0.8 \mathrm{mmol} / \mathrm{l}$ sulphates, $0.8 \mathrm{mmol} / \mathrm{l}$ phosphates, $0.5 \mathrm{mmol} / \mathrm{l}$ calcium chloride, $5 \mathrm{mmol} / \mathrm{l}$ glucose, $0.24 \mathrm{ml} / \mathrm{l} \mathrm{THAM}$-buffer and has $325 \mathrm{mOsm} / \mathrm{l}$ of osmolarity. The deflated lungs were left in the rat, in situ [17], and at room temperature $\left(20^{\circ} \mathrm{C}\right)$ for 2 hours of warm ischemic time. After the 2 hours, the heart lung block were weighted and then perfused for 4 hours in an Isolated Perfused Lung system for rat and guinea pig system (IPL-2, Hugo Sachs Elektronik Harvard Apparatus, Germany) at different subnormothermic perfusion temperatures of $21^{\circ} \mathrm{C}, 24^{\circ} \mathrm{C}, 28^{\circ} \mathrm{C}$ and $32^{\circ} \mathrm{C}$ as well as a standard normothermic temperature of $37^{\circ} \mathrm{C}$. At the end of the 4 hours of EVLP, we performed an additional 5 minutes stress test where the perfusate flow was enabled to increase until automatized IPL-2 controller system reached a maximum pulmonary arterial pressure (PAP) of $15 \mathrm{cmH}_{2} \mathrm{O}$. The mean flow value with standard deviation recorded in the different groups were the following: a) $8.475+/-2.032$ $\mathrm{ml} / \mathrm{min}$ for the $21^{\circ} \mathrm{C}$ group, b) $15.65+/-3.156 \mathrm{ml} / \mathrm{min}$ for the $24^{\circ} \mathrm{C}$ group, c) $15.68+/-3.519$ $\mathrm{ml} / \mathrm{min}$ for the $28^{\circ} \mathrm{C}$ group, d) $16.65+/-1.428 \mathrm{ml} / \mathrm{min}$ for the $32^{\circ} \mathrm{C}$ group and d) $14.63+/-$ $2.503 \mathrm{ml} / \mathrm{min}$ for the $37^{\circ} \mathrm{C}$ group.

Physiological variables and clinical biochemistry parameters. We monitored all the respiratory parameters under positive pressure ventilation with a dedicated software (PULMODYN $®$ software, Hugo Sachs Elektronik Harvard Apparatus, Germany) for 4 hours and recorded continuously the pulmonary artery pressure, the peak airway pressure, the airway flow, the dynamic lung compliance (Cdyn) and the pulmonary vascular resistance (PVR).

Hourly, and 5 min after switching lung ventilation with a fraction of inspired oxygen $\left(\mathrm{FiO}_{2}\right)$ of 1 , we collected samples for $\mathrm{pH}$, partial pressure of oxygen $\left(\mathrm{PaO}_{2}\right)$, concentration of potassium, calcium, sodium, glucose, chlorine and lactate measurement with the Epoc $\mathbb{R}$ blood analysis system (Epoc ® Blood Analysis System, Siemens Healthineers, Erlangen, Germany). The change in $\mathrm{PaO}_{2}\left(\Delta \mathrm{PaO}_{2}\right)$ was calculated as partial pressure of the pulmonary venous $\mathrm{PO}_{2}$-pulmonary arterial $\mathrm{PO}_{2}$.

Normothermic and subnormothermic EVLP treatment groups. As an acellular perfusate, we selected a starting volume of $125 \mathrm{~mL}$ of Steen solution (Steen solution, XVIVO Perfusion $\mathrm{AB}$, Göteborg, Sweden) supplemented with $300 \mathrm{IU}$ sodium heparin, antibiotic (50 mg meropenem), and methylprednisolone (50 mg Solu-Medrol, Pfizer Inc., New York, USA) that was recirculated during the 4 hours of EVLP (about 23 times recirculated). Before the start of the EVLP procedure, we oxygenated the Steen perfusate solution. The equilibrium of perfusate's dissolved $\mathrm{O}_{2}$ content was reached at $20^{\circ} \mathrm{C}$ after $15 \mathrm{~min}$ at a $30 \mathrm{~mL} / \mathrm{min}$ flow through a gas exchange membrane (D-150 hemofilter, Medsulfone, Italy) with 2 liters per minute flow of $100 \%$ oxygen. The $100 \%$ targeted flow was calculated as the $20 \%$ of a $250 \mathrm{~g}$ weight rat with a 75 $\mathrm{mL} / \mathrm{min}$ cardiac output. We started lung perfusion with $10 \%$ of the targeted flow $(1.5 \mathrm{~mL} / \mathrm{min})$ for 10 minutes. The five following 10 minutes steps in $\mathrm{ml} / \mathrm{min}$ were $3 \mathrm{ml} / \mathrm{min}, 4.5 \mathrm{ml} / \mathrm{min}, 7.5$ $\mathrm{ml} / \mathrm{min}, 12 \mathrm{ml} / \mathrm{min}(120 \mathrm{~mL})$. Then at the $50 \mathrm{~min}$ time point we switched to maximum flow of $15 \mathrm{ml} / \mathrm{min}$ and kept it for 3 hours and 10 minute until the end of the experiment. The left atrium pressure was set at $2-3 \mathrm{cmH}_{2} \mathrm{O}$ and the automatized IPL-2 controller system maintained the pulmonary arterial pressure (PAP) below $15 \mathrm{cmH}_{2} \mathrm{O}$ by adjusting the flow. The circuit perfusate temperature was set at $20^{\circ} \mathrm{C}$ to match the room temperature of $20^{\circ} \mathrm{C}$ used during the 2 hours warm ischemic time and was gradually increased using a thermostatic water bath and the targeted temperatures were reached after 15 minutes for the of $21^{\circ} \mathrm{C}, 24^{\circ} \mathrm{C}$ and $28^{\circ} \mathrm{C}$ groups and after 25 minutes for the $32^{\circ} \mathrm{C}$ and $37^{\circ} \mathrm{C}$ groups and kept onwards during the 4-hour time of EVLP. Ventilation with the IPL-2 ventilator (VCM-P, Hugo Sachs Elektronik Harvard Apparatus, Germany) started for all the groups after 20 min reperfusion time with a fixed tidal volume of $5 \mathrm{~mL} / \mathrm{kg}$, an inspiratory/expiratory ratio of $1 / 3$ and a rate of 30 breaths $/ \mathrm{min}$ and with a PEEP of $3 \mathrm{cmH}_{2} \mathrm{O}$ and a $\mathrm{FiO}_{2}$ of 0.21 . Thereafter, the perfusate was 
constantly deoxygenated with a mixture of $8 \% \mathrm{CO}_{2}$ and $92 \% \mathrm{~N}_{2}$ using a gas exchange membrane (D-150 hemofilter, Medsulfone, Italy).

\section{Biochemical measurements}

Cytokines, chemokines and mediators of tissue repair. The perfusate collected after 4 hours of EVLP were flash frozen in liquid nitrogen and stored at $-80^{\circ} \mathrm{C}$ until testing with a rat multiplex panel (Milliplex @ Magnetic Bead Panel; Millipore, Billerica, MA, USA) according to the manufacturer's instructions. We assessed $50 \mu \mathrm{L}$ of the perfusate for different interleukins (IL) IL-1 $\alpha$, IL-1 $\beta$, IL-6, IL-18, and chemokines such as monocyte chemoattractant protein 1 (MCP-1), macrophage inflammatory protein-2 (MIP2), macrophage inflammatory protein-1 $\alpha$ (MIP-1 $\alpha$ ) GRO/KC/CINC-1 and for the growth factor modulator of tissue repair VEGF.

ATP content, myeloperoxidase activity, carbonylated protein assays in lung tissues. At the end of EVLP, the rat lung tissues were collected and flash frozen in liquid nitrogen and then stored at $-80^{\circ} \mathrm{C}$. Frozen lung tissues were crushed on dry ice and the powdered tissues were used to prepare the lysates. ATP content was determined from $25 \mathrm{mg}$ of powdered lung tissue and extracted in $0.5 \mathrm{~mL}$ of $0.5 \%$ trichloroacetic acid and centrifuged at $8000 \mathrm{rpm}$ for 2 $\min$ at $4^{\circ} \mathrm{C}$. The supernatant was isolated, and $10 \mathrm{X}$ Tris-acetate was added to neutralize the $\mathrm{pH}$ to 7.4 with a $10 \mu \mathrm{L}$ of $0.002 \%$ xylenol blue used as $\mathrm{pH}$ indicator. ATP concentration in the supernatant was determined enzymatically with an ATP assay kit (Enliten,; Promega, Madison, WI, USA) by measuring in the luminescence channel of a Cytation 5 plate reader (BioTek Instruments, Inc., Winooski, VT, USA). Tissue lysates extracted from the powdered lung tissue were also analyzed using 1 ) a myeloperoxidase (MPO) activity assay (OxiSelect ${ }^{\text {tw }}$ myeloperoxidase chlorination activity assay, Cell Biolabs San Diego, CA, USA) and 2) an ELISA-based carbonylated proteins assay (OxiSelect ${ }^{\text {tw }}$ carbonyl protein ELISA assay, Cell Biolabs San Diego, CA, USA) according to manufacturer's instructions. A microBCA protein assay kit was used with bovine serum albumin as standard to determine protein concentration in the supernatant according to the manufacturer's instructions (Thermo Scientific, Rockford, Il, USA).

\section{Lung tissue TUNEL analysis after EVLP}

A terminal deoxynucleotidyl transferase dUTP nick end labeling (TUNEL) assay was performed on Leica Bond RX using Refine AP-Kit (Leica DS9800) including all the buffer-solutions from Leica Microsystems Newcastle, Ltd. and processed according to the manufacturer guidelines. The antigen retrieval was performed with LEICA Enzyme Pretreatment Kit Cat. AR9551 for $25 \mathrm{~min}$ at $37^{\circ} \mathrm{C}$. Paraffin-slides were dewaxed, pretreated and incubated with mouse anti-DIG FITC Jackson Immuno-Research, Cat: 200-092-156 at 1:500 dilution and a rabbit anti-FITC (Serotec Cat. 4510-7804 at 1:1000 dilution + 2\% normal mouse serum). The TdT-Enzyme were the following; $1 \mathrm{~mL}$ antibody-diluent (Leica AR9352), $100 \mu \mathrm{L}$ TdT-Buffer ((TUNEL-Box), M1893, Promega, Madison, WI, USA), $1 \mu \mathrm{L}$ dUTP (TUNEL-Box) DIG11-dUTP (Roche Cat: 11570013 910), $4 \mu$ L TdT-Enzyme ((TUNEL-Box), M1875, Promega, Madison, WI, USA). The cytoplasm of apoptotic cells contained red granules and the number of apoptotic cells in 10 random high-power fields (X400) was calculated. The apoptotic index was expressed as the number of apoptotic cells/100 cells (\%).

\section{Statistical method}

Results are expressed as mean and standard deviation (SD). For cytokine analysis the median and interquartile range (IQR) was used as measures of central tendency and dispersion, respectively. A nonparametric Mann-Whitney U-test was used for non-continuous data. Data 
with a time component were compared without assuming sphericity using 2-way analysis of variance (ANOVA) and the Geisser-Greenhouse correction. Statistical analysis was performed with GraphPad Prism version 8 software (GraphPad Software, Inc., La Jolla, CA, USA). Differences were considered significant at $p<0.05$.

\section{Results}

\section{Lung physiology during EVLP}

PVR at $21^{\circ} \mathrm{C}$ showed significantly higher values than all the other perfusion temperature conditions (Fig $1 \mathrm{~A}$ insert, $p<0.01$ ). We observed that the PVR within the 4 hours at $32^{\circ} \mathrm{C}$ subnormothermic was also lower but this difference was not statistically different from the control EVLP performed at $37^{\circ} \mathrm{C}$. The PVR value at 4 hours of EVLP done at $24^{\circ} \mathrm{C}$ and $28^{\circ} \mathrm{C}$ were comparable to the PVR values at $37^{\circ} \mathrm{C}$. Cdyn at $28^{\circ} \mathrm{C}$ showed higher values toward that recorded at $37^{\circ} \mathrm{C}$, but was not statistically different (Fig $1 \mathrm{~B}$ ) whereas Cdyn at $21^{\circ} \mathrm{C}$ and $24^{\circ} \mathrm{C}$ showed a not statistically different lower values. Cdyn values in EVLP done at $32^{\circ} \mathrm{C}$ and $28^{\circ} \mathrm{C}$ were overlapping the one recorded at $37^{\circ} \mathrm{C}$. The oxygenation at subnormothermic $21^{\circ} \mathrm{C}$ and $24^{\circ} \mathrm{C}$ temperatures showed a statistically better oxygenation compared to that of $37^{\circ} \mathrm{C}$ (Fig $1 \mathrm{C}$, $p<0.01$ ) whereas oxygenation at $28^{\circ} \mathrm{C}$ and $32^{\circ} \mathrm{C}$ were also higher although this difference was not statistically different from the control EVLP performed at $37^{\circ} \mathrm{C}$. We also observed edema formation after 4 hours of EVLP for the subnormothermic $21^{\circ} \mathrm{C}$ condition with a significantly

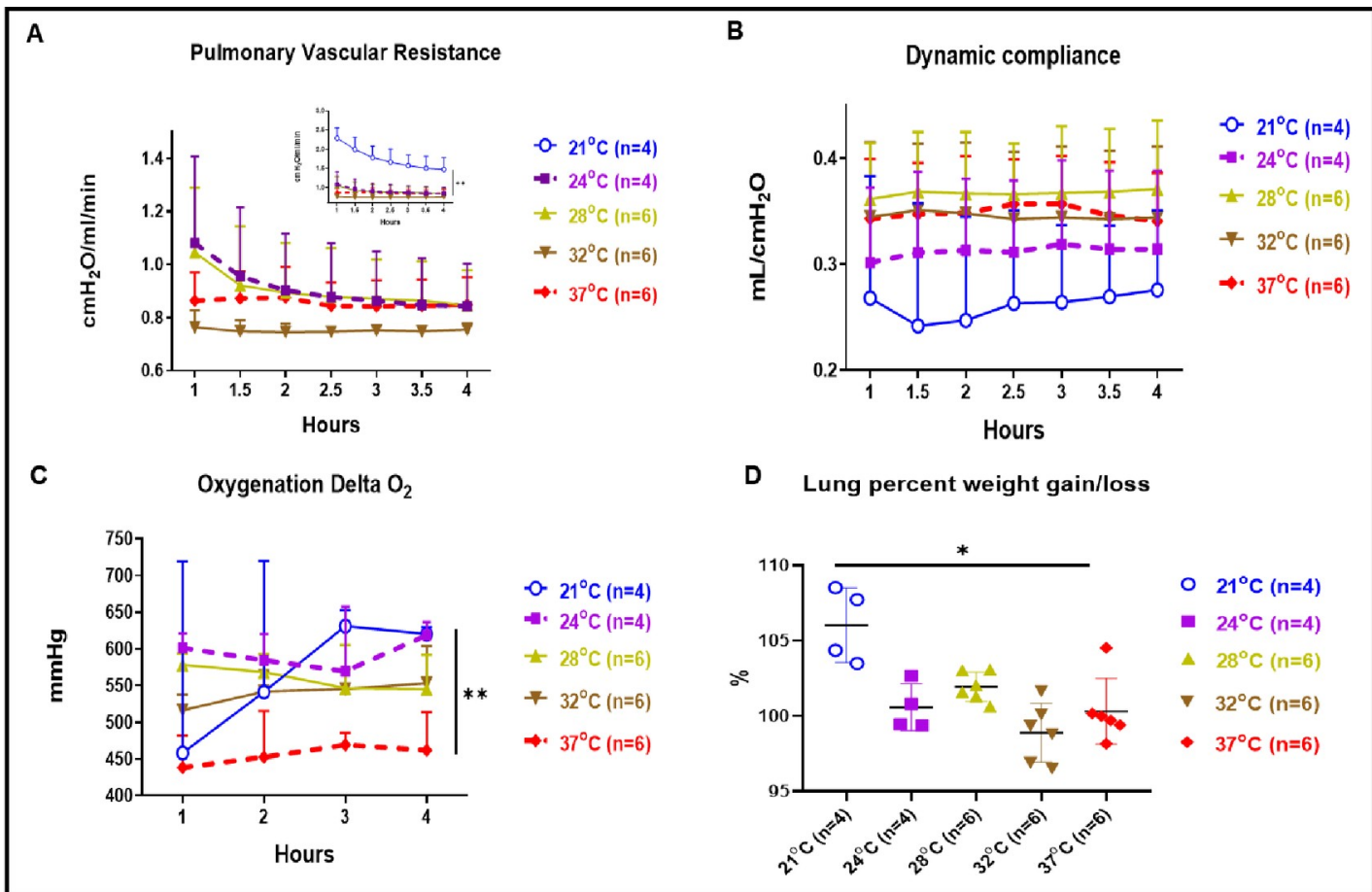

Fig 1. Physiological variables and oxygenation parameters. (A) PVR at $21^{\circ} \mathrm{C}$ was significantly higher than those at $37^{\circ} \mathrm{C}$ $(p<0.01)$ (see Fig $1 \mathrm{~A}$ insert). PVR at $32^{\circ} \mathrm{C}$ were with a lower but not statistically different value compared to PVR at $37^{\circ} \mathrm{C}$. PVR at $28^{\circ} \mathrm{C}$ and $24^{\circ} \mathrm{C}$ were comparable to PVR at $37^{\circ} \mathrm{C}$. (B) Cdyn at $21^{\circ} \mathrm{C}$ and $24^{\circ} \mathrm{C}$ showed a not significantly different lower value than those at $37^{\circ} \mathrm{C}$. Cdyn at $28^{\circ} \mathrm{C}$ and $32^{\circ} \mathrm{C}$ were similar to Cdyn at $37^{\circ} \mathrm{C}$. (C) Perfusate oxygenation (delta $\mathrm{PO}_{2}$ or left atrial pressure of oxygen minus pulmonary arterial pressure of oxygen) was significantly improved at $24^{\circ} \mathrm{C}$ and $21^{\circ} \mathrm{C}(p<0.01)$ and were higher at $28^{\circ} \mathrm{C}$ and $32^{\circ} \mathrm{C}$ although this difference was not statistically different from the control EVLP performed at $37^{\circ} \mathrm{C}$. (D) Percentage of gain/loss in lung weight after 4 hours of EVLP was significantly higher at $21^{\circ} \mathrm{C}$ when compared to $37^{\circ} \mathrm{C}$ normothermic temperature $(p<0.05)$.

https://doi.org/10.1371/journal.pone.0255155.g001 
higher percentage gain of lung weight when compared to 4 hours of EVLP performed at $37^{\circ} \mathrm{C}$

(Fig 1D, $p<0.05$ ).

\section{Clinical biochemistry parameters}

Perfusate concentrations of potassium ions at $28^{\circ} \mathrm{C}$ were significantly lower than that of $37^{\circ} \mathrm{C}$ and $32^{\circ} \mathrm{C}$ (Fig $2 \mathrm{~A}, p<0.05$ and $p<0.01$, respectively). Concentration for potassium ions at $24^{\circ} \mathrm{C}$ and $21^{\circ} \mathrm{C}$ were similar to that of $37^{\circ} \mathrm{C}$. Perfusate concentrations of lactate at $21^{\circ} \mathrm{C}$ and $28^{\circ} \mathrm{C}$ were significantly lower than that of $37^{\circ} \mathrm{C}$ (Fig $2 \mathrm{~B}, p<0.05$ ). Calcium concentrations after 4 hours were at their lowest level at $28^{\circ} \mathrm{C}$, higher at $32^{\circ} \mathrm{C}$ and $24^{\circ} \mathrm{C}$ and significantly higher at $21^{\circ} \mathrm{C}$ compared to the normothermic $37^{\circ} \mathrm{C}$ condition, (Fig $2 \mathrm{C}, p<0.05$ ). Perfusate glucose concentrations were significantly higher at $32^{\circ} \mathrm{C}$ compared to the normothermic $37^{\circ} \mathrm{C}$ condition, (Fig 2D, $p<0.01$ ). Concentrations of sodium and chlorine were at their lowest level at $28^{\circ} \mathrm{C}$ whereas at $32^{\circ} \mathrm{C}$ they were significantly higher than that of $37^{\circ} \mathrm{C}$ (Fig $2 \mathrm{E}$ and $2 \mathrm{~F} p<0.05$ respectively).

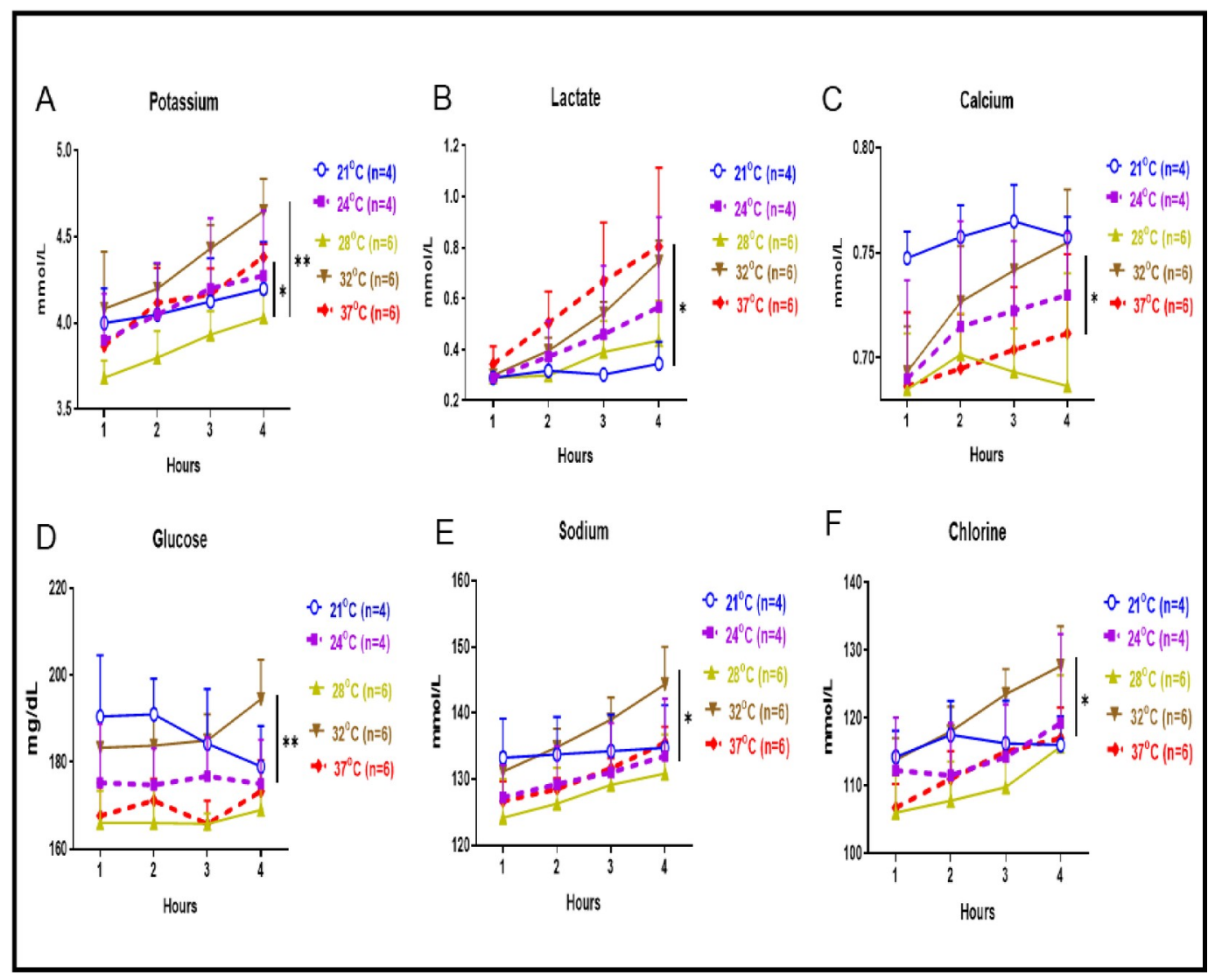

Fig 2. Clinical biochemistry parameters. (A) Concentration of potassium at $28^{\circ} \mathrm{C}$ was significantly lower than $37^{\circ} \mathrm{C}$ and $32^{\circ} \mathrm{C}\left(p<0.05\right.$ and $p<0.01$ respectively), but potassium ion concentration obtained at $24^{\circ} \mathrm{C}$ and $21^{\circ} \mathrm{C}$ was similar to that of $37^{\circ} \mathrm{C}$. (B) Lactate levels at $21^{\circ} \mathrm{C}$ and $28^{\circ} \mathrm{C}$ were significantly lower than that of $37^{\circ} \mathrm{C}(p<0.05)$. Lactate levels at $32^{\circ} \mathrm{C}$ and $24^{\circ} \mathrm{C}$ were similar to that of $37^{\circ} \mathrm{C}$. (C) Calcium ion perfusate concentrations was at their lowest level at $28^{\circ} \mathrm{C}$, higher at $32^{\circ} \mathrm{C}$ and $24^{\circ} \mathrm{C}$ and were significantly higher at $21^{\circ} \mathrm{C}$ compared to the $37^{\circ} \mathrm{C}$ condition $(p<0.05)$. (D) Perfusate glucose concentration was significantly higher at $32^{\circ} \mathrm{C}$ compared to the $37^{\circ} \mathrm{C}$ condition $(p<0.01)$. (E) Sodium ion concentration was at their lowest level at $28^{\circ} \mathrm{C}$ and significantly higher at $32^{\circ} \mathrm{C}$ compared to the normothermic $37^{\circ} \mathrm{C}(p<0.05)$. (F) Chlorine ion concentrations was at their lowest level at $28^{\circ} \mathrm{C}$ and significantly higher at $32^{\circ} \mathrm{C}$ compared to the normothermic $37^{\circ} \mathrm{C}$ $(p<0.05)$. 


\section{Perfusate cytokines, chemokines and mediators of tissue repair}

Both macrophage inflammatory protein- $1 \alpha$ (MIP- $1 \alpha)$ and macrophage inflammatory protein2 (MIP2) concentrations at $21^{\circ} \mathrm{C}, 24^{\circ} \mathrm{C}$ and $28^{\circ} \mathrm{C}$ were significantly lower than at $37^{\circ} \mathrm{C}$ (Fig $3 \mathrm{~A}$ and $3 \mathrm{~B}, p<0.05$ to $p<0.01$ ), but that of $32^{\circ} \mathrm{C}$ were not statistically different from the normothermic condition. Growth-regulated oncogene- $\alpha$ (GRO- $\alpha$ ) and interleukin- 6 (IL- 6$)$ concentrations were significantly lower at all subnormothermic temperatures comparing to $37^{\circ} \mathrm{C}$ (Fig $3 \mathrm{C}$ and $3 \mathrm{D}, p<0.05$ to $p<0.01$ ). Interleukin- 18 (IL-18) levels at $21^{\circ} \mathrm{C}$ were significantly lower than the levels of the normothermic condition (Fig 3E, $p<0.05$ ) whereas IL-18 levels detected at $24^{\circ} \mathrm{C}, 28^{\circ} \mathrm{C}$ and $32^{\circ} \mathrm{C}$ showed lower but not statistically different values toward levels observed at $37^{\circ} \mathrm{C}$. Interleukin- $1 \beta(\mathrm{IL}-1 \beta)$ levels at $21^{\circ} \mathrm{C}$ and $24^{\circ} \mathrm{C}$ were statistically lower than levels of IL- $1 \beta$ at $37^{\circ} \mathrm{C}$ (Fig 3F, $p<0.01$ ). For Interleukin- $1 \alpha$ (IL-1 $\alpha$, Fig 3G), Monocyte chemoattractant protein 1 (MCP-1, Fig $3 \mathrm{H})$ and Vascular endothelial growth factor (VEGF,

A

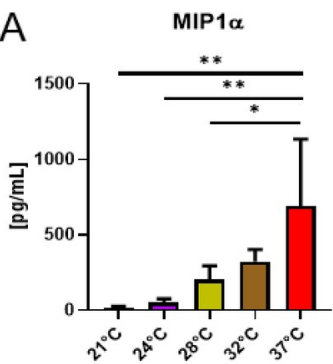

D

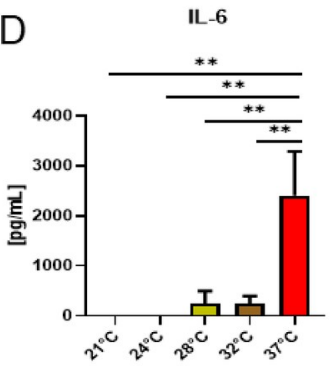

G

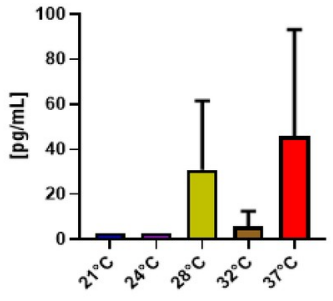

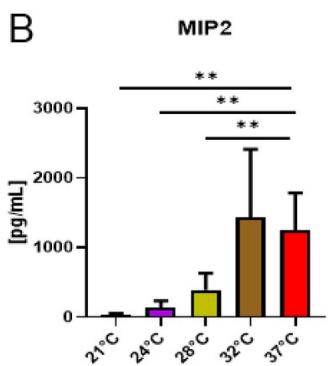

E

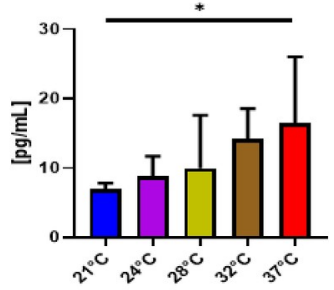

$\mathrm{H}$

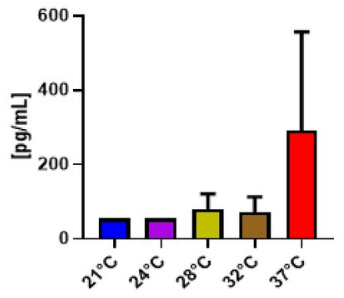

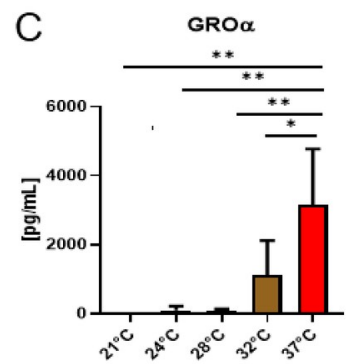

$\mathrm{F}$

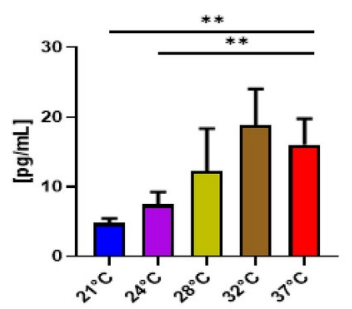

I

VEGF

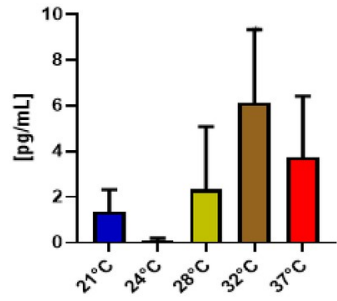

Fig 3. Cytokines and chemokines in the perfusate. After 4 hours of EVLP, concentrations of chemokines MIP1 $\alpha$ (Fig $3 \mathrm{~A}$ ) and MIP2 (Fig 3B) collected from the $28^{\circ} \mathrm{C}, 24^{\circ} \mathrm{C}$ and $21^{\circ} \mathrm{C}$ conditions were significantly lower than at $37^{\circ} \mathrm{C}$ $(p<0.05$ to $p<0.01)$. Concentrations of GRO- $\alpha$ (Fig 3C) and IL-6 (Fig 3D) collected from all the subnormothermic conditions were significantly lower than at $37^{\circ} \mathrm{C}(p<0.05$ to $p<0.01)$. Concentration of IL-18 (Fig 3E) at $21^{\circ} \mathrm{C}$ was significantly lower than at $37^{\circ} \mathrm{C}(p<0.05)$, whereas IL-18 levels detected at $24^{\circ} \mathrm{C}, 28^{\circ} \mathrm{C}$ and $32^{\circ} \mathrm{C}$ were lower but not significantly different from levels observed at $37^{\circ} \mathrm{C}$. Concentrations of IL- $1 \beta$ (Fig $3 \mathrm{~F}$ ) at $21^{\circ} \mathrm{C}$ and $24^{\circ} \mathrm{C}$ were lower than at $37^{\circ} \mathrm{C}(p<0.01)$. For IL-1 $\alpha$ (Fig 3G), MCP-1 (Fig 3H) and VEGF (Fig 3I), their concentrations showed lower values compared to $37^{\circ} \mathrm{C}$.

https://doi.org/10.1371/journal.pone.0255155.g003 
Fig 3I), concentrations showed only reduced concentration values but not statistically different compared to $37^{\circ} \mathrm{C}$ concentrations.

\section{TUNEL assay, myeloperoxidase activity, ATP and carbonylated protein content in lung tissues}

In Fig $4 \mathrm{~A}$, the tissue ATP content at $28^{\circ} \mathrm{C}(p<0.05)$ and $21^{\circ} \mathrm{C}(p<0.01)$ or $24^{\circ} \mathrm{C}(p<0.01)$ were significantly higher than at $37^{\circ} \mathrm{C}$. ATP content of tissue with EVLP performed at $32^{\circ} \mathrm{C}$ was comparable to normothermic condition. As shown in Fig 4B, the MPO activities detected in lung tissue from the $28^{\circ} \mathrm{C}$ and $37^{\circ} \mathrm{C}$ EVLP were similar whereas significantly higher MPO activities were observed in tissue from EVLP performed at $21^{\circ} \mathrm{C}, 24^{\circ} \mathrm{C}$ and $32^{\circ} \mathrm{C}(p<0.05)$. Carbonylated protein contents in lung tissues after $28^{\circ} \mathrm{C}$ EVLP were significantly lower than that of $37^{\circ} \mathrm{C}$ (Fig $4 \mathrm{C}, p<0.05$ ) but there was no statistical differences among $21^{\circ} \mathrm{C}, 24^{\circ} \mathrm{C}$ and $32^{\circ} \mathrm{C}$ conditions compared to the normothermic temperature. TUNEL analysis in lung tissue showed lower but not statistically different values towards less apoptotic cell damage in subnormothermic temperature of $24^{\circ} \mathrm{C}$ and $21^{\circ} \mathrm{C}$ (Fig 4D).

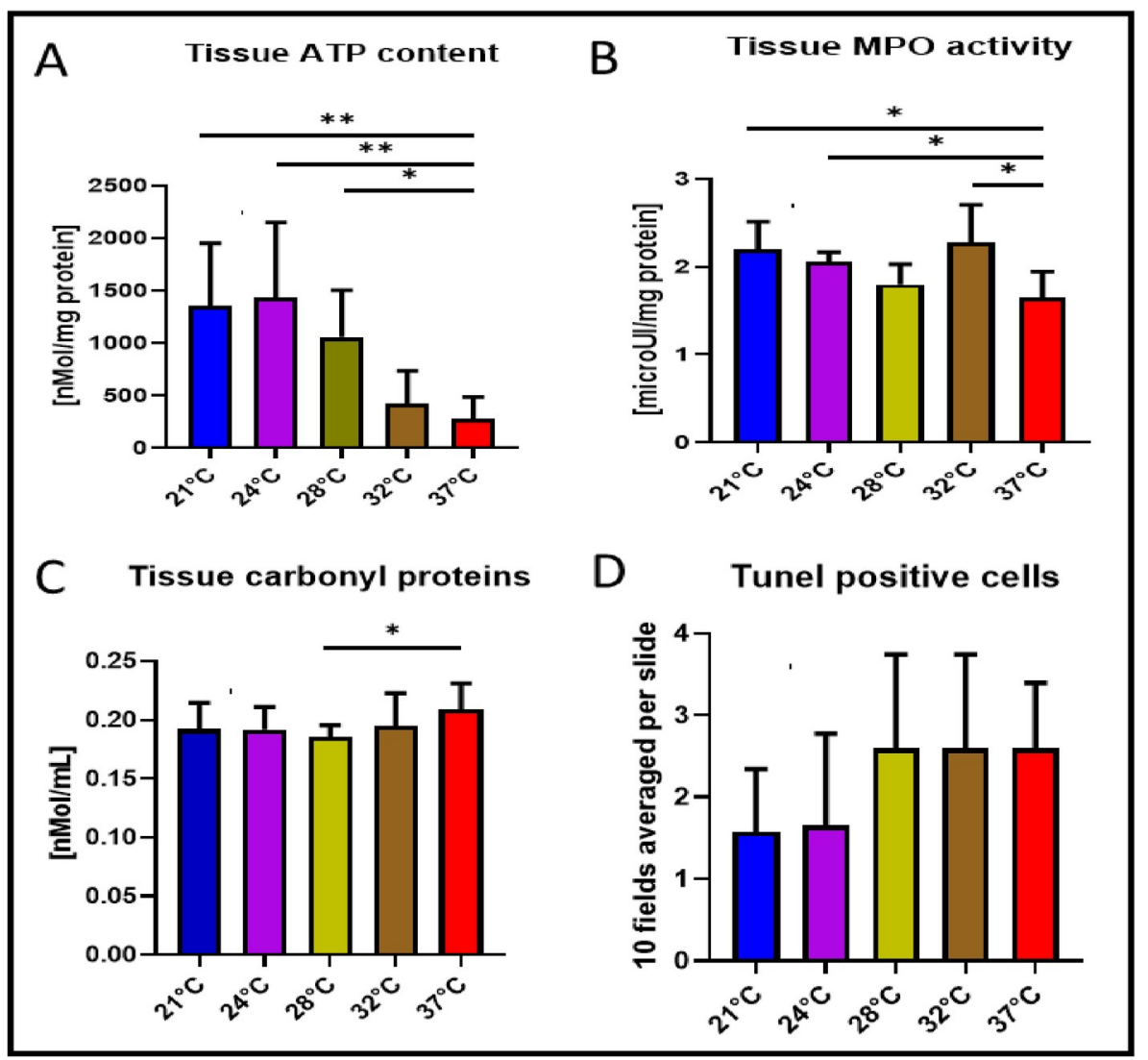

Fig 4. TUNEL assay, Myeloperoxidase activity, ATP and carbonylated protein content in lung tissues. (A) ATP content in lung tissue was significantly higher at $24^{\circ} \mathrm{C}$ and $21^{\circ} \mathrm{C}(p<0.01)$ or $28^{\circ} \mathrm{C}(p<0.05)$ versus ATP tissue content at $37^{\circ} \mathrm{C}$. (B) MPO activity in lung tissue after 4 hours of EVLP at $28^{\circ} \mathrm{C}$ were close to the value at $37^{\circ} \mathrm{C}$, whereas significantly higher MPO activity were observed in tissue from EVLP performed at $21^{\circ} \mathrm{C}$ or $24^{\circ} \mathrm{C}$ and $32^{\circ} \mathrm{C}(p<0.05)$. (C) Carbonylated protein level was significantly lower at $28^{\circ} \mathrm{C}(p<0.05)$ versus lung tissue exposed to $37^{\circ} \mathrm{C}$ EVLP. (D) TUNEL analysis in histological preparation of lung tissue showed lower but not statistically different values towards less apoptotic cell damage in subnormothermic temperature of $24^{\circ} \mathrm{C}$ and $21^{\circ} \mathrm{C}$.

https://doi.org/10.1371/journal.pone.0255155.g004 


\section{Discussion}

Since the implementation of DCD lung transplantation in some countries, this procedure has dramatically increased the donation rate by 20 to 50\% [18]. The advent of EVLP in lung transplantation has also shown immense potential, which has resulted in improved post-transplant outcomes. The DCD lung physiology is degraded due to the metabolic damages sustained by the warm ischemic time [19]. Nonetheless in 2001, the group of Steen el al [20] restored with EVLP the oxygenation and the substrates flow to human DCD lungs and performed the first successful human lung transplantation of uncontrolled DCD donors. Normothermic perfusion temperature is the current standard for machine perfusion assessment of the lung before transplantation. However, subnormothermic perfusion temperature settings are already in human clinical use among several human solid organs or tested in animals [6-11, 14, 15]. In order to evaluate if subnormothermic temperatures might impact the physiological, biochemical and immunological parameters of the lungs, we exposed rat lungs for 2 hours of warm ischemic time at room temperature and then performed subnormothermic machine perfusion for 4 hours at $32^{\circ} \mathrm{C}, 28^{\circ} \mathrm{C}, 24^{\circ} \mathrm{C}$ and $21^{\circ} \mathrm{C}$ with a dedicated rat EVLP platform. We found that EVLP at $28^{\circ} \mathrm{C}$ compared to the normorthermic situation had acceptable physiological variables, significant improvement in tissue ATP content and both decreased tissue MPO activity and carbonylated proteins with reduced release of pro-inflammatory cytokines.

The use of acellular machine perfusion for organ preservation [21] and the application of hypothermia was already described in liver $[9,10,22-24]$ in heart $[25,26]$ in kidney [11] in injured lungs [27], and in rat lung machine perfusion [12, 13, 28, 29]. The assessment of donor lung quality during EVLP mainly relies on the monitoring of airway pressure, pulmonary artery pressure, and oxygen concentration. Here, in a rat EVLP model of DCD lung donors we report that the oxygenation data were significantly improved at $21^{\circ} \mathrm{C}$ and $24^{\circ} \mathrm{C}$ but not statistically different than those at $32^{\circ} \mathrm{C}$ and $28^{\circ} \mathrm{C}$. An obvious physicochemical explanation for this improved oxygenation data is that gases are better kept in a soluble phase with low temperature acellular perfusate as compared to perfusion done at $37^{\circ} \mathrm{C}$.

The PVR value of EVLP done at $32^{\circ} \mathrm{C}$ showed a not statistically different lower values compared to the $37^{\circ} \mathrm{C}$ EVLP condition whereas the Cdyn values at $28^{\circ} \mathrm{C}$ and $32^{\circ} \mathrm{C}$ were comparable to the $37^{\circ} \mathrm{C}$. An hypothesis for the poor PVR and Cdyn values at $21^{\circ} \mathrm{C}$ and $24^{\circ} \mathrm{C}$ may have been the deleterious effect of cold on either the blood vessels (vasoconstriction) or the lung parenchyma or on the biophysical properties of surfactant. As a consequence of this, we observed a significant higher weight for the lung perfused at $21^{\circ} \mathrm{C}$ due to edema formation when compared to normothermic temperature. It has been reported that during the months of hibernation which is a natural and complex physiological and metabolic response to cold temperature developed in mammals that lung present tissue remodelling [30-32] and that the lung surfactant composition was also adapted to the cold [33]. In comparison to those long cold hibernating time adaptation of the lung in our EVLP setting was short and did probably not allow enough time for any lung tissue remodelling. In brief, all these physiological data (PVR, edema, Cdyn, delta $\mathrm{PO}_{2}$,) point towards a protective effect of subnormothermic perfusion temperature in the $28^{\circ} \mathrm{C}$ to $32^{\circ} \mathrm{C}$ range with a better physiological state of the DCD donor graft after 4 hours of EVLP compared to the $37^{\circ} \mathrm{C}$ situation. Contrary to this, we observed a more deleterious effect of subnormothermic temperature on the Cdyn and edema formation of the lungs treated at $24^{\circ} \mathrm{C}$ and $21^{\circ} \mathrm{C}$.

As both the liver and kidneys are absent from acellular organ machine perfusion protocols, the circulating concentration of potassium, sodium, and lactate increases as the $\mathrm{pH}$ drops. We recorded comparable values for $\mathrm{pH}$ (data not shown), sodium and chlorine at $28^{\circ} \mathrm{C}$ when compared to $37^{\circ} \mathrm{C}$ situation. The potassium levels in a perfusate may also be used as an indirect 
proxy for cell integrity [34] and cell death [35]. We obtained at $28^{\circ} \mathrm{C}$ significantly lower concentrations of potassium versus the $37^{\circ} \mathrm{C}$ and $32^{\circ} \mathrm{C}$ conditions, whereas sodium and chlorine concentrations had a lower but not significantly different values at $28^{\circ} \mathrm{C}$ versus the normothermic condition. The low potassium levels might be explained by less cell lysis at low perfusion temperature. The anaerobic glycolysis is the process by which the normal pathway of glycolysis is routed to produce lactate and this metabolic waste products will accumulate over time [36]. Lactate accumulation occurs at times when energy is required in the absence of oxygen. The preoperative serum lactate levels is a strong independent predictor of worse outcomes in patients undergoing urgent heart transplant on short-term mechanical circulatory support [37]. Nonetheless, for patients who underwent lung transplantation after EVLP had good outcomes despite high lactate during EVLP [36]. In our experiments, the lactate concentrations at $28^{\circ} \mathrm{C}$ and at $21^{\circ} \mathrm{C}$ were significantly lower than those at $37^{\circ} \mathrm{C}$ and we could also record a gradual decrease/consumption of glucose in all of the subnormothermic or control perfusate conditions but the consumption of glucose were only significantly higher at $32^{\circ} \mathrm{C}$. Since there are no compensatory mechanisms in this EVLP setting, the decreased lactate levels or reduced glucose consumption levels may indicate respectively reduced anaerobic glycolysis in the $28^{\circ} \mathrm{C}$ and $21^{\circ} \mathrm{C}$ groups and higher anaerobic glycolysis in the $32^{\circ} \mathrm{C}$ group. These changes may mainly be attributable to the pneumocyte metabolism that occurs when energy is required in the absence of oxygen. When compared to the normothermic temperature, the concentrations of calcium were significantly higher at $21^{\circ} \mathrm{C}$. This hypercalcemia is possibly related to the cell death related release of intracellular calcium into the perfusate and this excessive entry of calcium into the lung parenchyma might have damaged it or even caused it to undergo apoptosis, or death by necrosis. Calcium also acts as one of the primary regulators of osmotic stress and we observed a significant higher weight of the lungs after EVLP done at $21^{\circ} \mathrm{C}$. All these clinical chemistry data in EVLP perfusate for potassium, calcium, sodium and chlorine ions but also lactate and glucose point towards a beneficial effect of the $28^{\circ} \mathrm{C}$ subnormothermic perfusate temperature compared to the $37^{\circ} \mathrm{C}$ situation and a rather deleterious effect at $21^{\circ} \mathrm{C}$ and $32^{\circ} \mathrm{C}$ temperature.

We selected a panel of cytokines, interleukins and growth factors to monitor their release during EVLP-induced I/R injury. Some pro-inflammatory cytokines and chemokines accumulate during EVLP and correlate with higher rates of primary graft dysfunction of the transplanted lungs [38]. In the perfusate at $28^{\circ} \mathrm{C}$, the detected amount of chemokines MIP1 $\alpha$, MIP2, GRO- $\alpha$ (KC is a rat homolog of human GRO- $\alpha$ ) and the cytokine IL-6 were significantly lower than at $37^{\circ} \mathrm{C}$. Other proteins recovered such as the chemokine MCP1, the cytokines IL-18, IL1 $\beta$ and IL1 $\alpha$ were not always detected in each perfusates but they nonetheless showed a lower but not significantly different release at subnormothermic temperature ranging from $21^{\circ} \mathrm{C}$ to $32^{\circ} \mathrm{C}$ when compared to the $37^{\circ} \mathrm{C}$ EVLP condition. We also observed the same gradual but not statistically different reduction of VEGF collected at subnormothermic temperature of $21^{\circ} \mathrm{C}, 24^{\circ} \mathrm{C}$ and $28^{\circ} \mathrm{C}$ when compared to the value at $37^{\circ} \mathrm{C}$.

Finally, several biochemical parameters were also improved with sunormothermic perfusion temperature. Generally, I/R injury occurs when the blood supply to tissue is blocked (ischemic time) [39]. It has been hypothesized that after stopping the flow in the lung endothelium and during the cold preservation graft ischemic time but also when flow is reinstated (reperfusion time) that a mechanosignaling cascade initiate a sodium ions influx and persistent cell membrane depolarization due to a decrease of intracellular potassium ions. Moreover, during the graft cold ischemic time the cell calcium and ATP storage are depleted leading to alteration in mitochondrial membrane permeability and depolarization of their membrane potential [40]. Once organ reperfusion is performed the mitochondrial permeability transition triggers both mitochondrial reactive oxygen species, generation and opening of mitochondrial 
permeability transition pore, ultimately leading to damage-associated molecular patterns release and tissue inflammation [41]. The ATP tissue content at the end of EVLP was significantly higher at $24^{\circ} \mathrm{C}, 21^{\circ} \mathrm{C}$ and $28^{\circ} \mathrm{C}$ showing an increased protective effect of these subnormothermic temperatures on keeping optimal mitochondrial activity. The reactive oxygen species are known to be a factor of injury during hypothermic time [42] both in liver [22, 43] and lung [44]. Protein carbonylation is a type of protein oxidation that can be promoted by reactive oxygen species $[45,46]$. The tissue content in carbonylated proteins were significantly lower at $28^{\circ} \mathrm{C}$ whereas only a not significantly different decrease of TUNEL quantified apoptotic cells could be observed in subnormothermic temperature of $24^{\circ} \mathrm{C}$ and $21^{\circ} \mathrm{C}$. Moreover, MPO enzymes which are released into the extracellular fluid as a result of oxidative stress or during an inflammatory response and probably issued from neutrophils, were significantly more active under $21^{\circ} \mathrm{C}, 24^{\circ} \mathrm{C}$ and $32^{\circ} \mathrm{C}$ subnormothermic conditions but MPO activities at $28^{\circ} \mathrm{C}$ remained close to the value at $37^{\circ} \mathrm{C}$. All these biochemical parameters in lung tissue after 4 hours of EVLP (ATP, apoptotic cells content, MPO and carbonyl proteins) point towards a beneficial effect of the $28^{\circ} \mathrm{C}$ temperature in the biochemical parameters of the DCD donor graft after 4 hours of EVLP compared to the $37^{\circ} \mathrm{C}$ situation and a rather deleterious effect of the $32^{\circ} \mathrm{C}, 24^{\circ} \mathrm{C}$ and $21^{\circ} \mathrm{C}$ temperatures.

Our study had some limitations. Lung function was assessed only during EVLP, but no further lung transplantation was performed and we did not use a leucocyte filter during EVLP which was documented to reduce the release of pro-inflammatory cytokine IL-6 in the perfusate and which absence impair the quality of the lung grafts [47].

Among our subnormothermic conditions, the $28^{\circ} \mathrm{C}$ perfusion was found to be the most promising because of acceptable physiology and both reduced energy consumption and immune response. EVLP with perfusate temperature of $28^{\circ} \mathrm{C}$ were physiologically comparable to the $37^{\circ} \mathrm{C}$ whereas EVLP at $21^{\circ} \mathrm{C}$ showed the worst lung physiological data. Nevertheless, at all the EVLP temperature lower than $28^{\circ} \mathrm{C}$, low energy consumption and low inflammatory response were recorded. Recently, Gloria et al. presented evidences after a 2-hour reperfusion time in transplanted recipient rats, that lung grafts treated pre-transplantation without EVLP but exposed to a 4-hour cold ischemic time have a worst outcome than their three experimental groups of undamaged lungs pretreated before transplantation with EVLP temperature set at either $25^{\circ} \mathrm{C}, 30^{\circ} \mathrm{C}$ or $37^{\circ} \mathrm{C}$ [14]. We recently published a study [15] where all the rat HBD lungs were pre-damaged by exposure to a 1-hour cold ischemic time to mimic as close as possible a clinical situation. In this study, and compared to the control $37^{\circ} \mathrm{C}$ normothermic EVLP setting, the HBD damaged lungs showed improved physiological parameters and attenuated $\mathrm{I} / \mathrm{R}$ injuries after both the $28^{\circ} \mathrm{C}$ subnormothermic for 4-hour EVLP time alone or in a combination of the $28^{\circ} \mathrm{C}$ subnormothermic for 4-hour EVLP time followed by a 2-hour time with left lung transplantation. The present article is the first study directly comparing different subnormothermic EVLP temperature with DCD rats donor lungs and we show that perfusion at $28^{\circ} \mathrm{C}$ have a strong benefit potential for both physiological parameters and attenuation of $\mathrm{I} / \mathrm{R}$ injury. Taken together all of our data, this study suggests that $28^{\circ} \mathrm{C} E V L P$ is a non inferior setting in comparison to the clinically approved $37^{\circ} \mathrm{C} \mathrm{EVLP}$ and may potentially reduce lung I/R injury of DCD donors. Large animal models are needed to further prove this conclusion.

\section{Author Contributions}

Conceptualization: Stephan Arni, Tatsuo Maeyashiki, Isabelle Opitz, Ilhan Inci.

Formal analysis: Stephan Arni, Tatsuo Maeyashiki.

Investigation: Stephan Arni, Tatsuo Maeyashiki. 
Methodology: Stephan Arni, Tatsuo Maeyashiki.

Supervision: Ilhan Inci.

Writing - original draft: Stephan Arni, Tatsuo Maeyashiki, Ilhan Inci.

Writing - review \& editing: Stephan Arni, Tatsuo Maeyashiki, Isabelle Opitz, Ilhan Inci.

\section{References}

1. Valapour M, Lehr CJ, Skeans MA, Smith JM, Uccellini K, Lehman R, et al. OPTN/SRTR 2017 Annual Data Report: Lung. Am J Transplant. 2019; 19 Suppl 2:404-84. Epub 2019/02/28. https://doi.org/10. 1111/ajt.15279 PMID: 30811892.

2. Inci I. Donors after cardiocirculatory death and lung transplantation. J Thorac Dis. 2017; 9(8):2660-9. Epub 2017/09/22. https://doi.org/10.21037/jtd.2017.07.82 PMID: 28932573; PubMed Central PMCID: PMC5594200.

3. Wierup $P$, Haraldsson A, Nilsson F, Pierre L, Schersten $H$, Silverborn $M$, et al. Ex vivo evaluation of nonacceptable donor lungs. Ann Thorac Surg. 2006; 81(2):460-6. Epub 2006/01/24. https://doi.org/10. 1016/j.athoracsur.2005.08.015 PMID: 16427831.

4. Cypel M, Yeung JC, Liu M, Anraku M, Chen F, Karolak W, et al. Normothermic ex vivo lung perfusion in clinical lung transplantation. N Engl J Med. 2011; 364(15):1431-40. Epub 2011/04/15. https://doi.org/ 10.1056/NEJMoa1014597 PMID: 21488765.

5. Galasso M, Feld JJ, Watanabe Y, Pipkin M, Summers C, Ali A, et al. Inactivating hepatitis C virus in donor lungs using light therapies during normothermic ex vivo lung perfusion. Nat Commun. 2019; 10 (1):481. Epub 2019/01/31. https://doi.org/10.1038/s41467-018-08261-z PMID: 30696822; PubMed Central PMCID: PMC6351537.

6. Fontes $\mathrm{P}$, Lopez R, van der Plaats $\mathrm{A}$, Vodovotz $\mathrm{Y}$, Minervini M, Scott $\mathrm{V}$, et al. Liver preservation with machine perfusion and a newly developed cell-free oxygen carrier solution under subnormothermic conditions. Am J Transplant. 2015; 15(2):381-94. Epub 2015/01/24. https://doi.org/10.1111/ajt.12991 PMID: 25612645; PubMed Central PMCID: PMC5024042.

7. Eshmuminov D, Becker D, Bautista Borrego L, Hefti M, Schuler MJ, Hagedorn C, et al. An integrated perfusion machine preserves injured human livers for 1 week. Nat Biotechnol. 2020; 38(2):189-98. Epub 2020/01/15. https://doi.org/10.1038/s41587-019-0374-x PMID: 31932726; PubMed Central PMCID: PMC7008032.

8. Obara H, Morito N, Matsuno N, Yoshikawa R, Gouchi M, Otani M, et al. Optimum Perfusate Volume of Purified Subnormothermic Machine Perfusion for Porcine Liver Donated After Cardiac Death. Transplant Proc. 2018; 50(9):2830-3. Epub 2018/11/08. https://doi.org/10.1016/j.transproceed.2018.03.055 PMID: 30401406

9. Vairetti M, Ferrigno A, Rizzo V, Richelmi P, Boncompagni E, Neri D, et al. Subnormothermic machine perfusion protects against rat liver preservation injury: a comparative evaluation with conventional cold storage. Transplant Proc. 2007; 39(6):1765-7. Epub 2007/08/19. https://doi.org/10.1016/j. transproceed.2007.06.002 PMID: 17692606.

10. Knaak JM, Spetzler VN, Goldaracena N, Louis KS, Selzner N, Selzner M. Technique of subnormothermic ex vivo liver perfusion for the storage, assessment, and repair of marginal liver grafts. J Vis Exp. 2014;(90):e51419. Epub 2014/08/26. https://doi.org/10.3791/51419 PMID: 25145990; PubMed Central PMCID: PMC4672992.

11. Bhattacharjee RN, Patel SVB, Sun Q, Jiang L, Richard-Mohamed M, Ruthirakanthan A, et al. Renal Protection Against Ischemia Reperfusion Injury: Hemoglobin-based Oxygen Carrier-201 Versus Blood as an Oxygen Carrier in Ex Vivo Subnormothermic Machine Perfusion. Transplantation. 2020; 104 (3):482-9. Epub 2019/10/01. https://doi.org/10.1097/TP.0000000000002967 PMID: 31568396.

12. Nakajima D, Chen F, Yamada T, Sakamoto J, Osumi A, Fujinaga $T$, et al. Hypothermic machine perfusion ameliorates ischemia-reperfusion injury in rat lungs from non-heart-beating donors. Transplantation. 2011; 92(8):858-63. Epub 2011/08/13. https://doi.org/10.1097/TP.0b013e31822d8778 PMID: 21832959.

13. Shoji $T$, Omasa M, Nakamura $T$, Yoshimura $T$, Yoshida $H$, Ikeyama K, et al. Mild hypothermia ameliorates lung ischemia reperfusion injury in an ex vivo rat lung model. Eur Surg Res. 2005; 37(6):348-53. Epub 2006/02/09. https://doi.org/10.1159/000090335 PMID: 16465059.

14. Gloria JN, Yerxa J, Kesseli SJ, Davis RP, Samoylova ML, Barbas AS, et al. Subnormothermic ex vivo lung perfusion attenuates graft inflammation in a rat transplant model. J Thorac Cardiovasc Surg. 2021. Epub 2021/03/01. https://doi.org/10.1016/j.jtcvs.2021.01.066 PMID: 33640121. 
15. Arni S, Maeyashiki T, Citak N, Opitz I, Inci I. Subnormothermic Ex Vivo Lung Perfusion Temperature Improves Graft Preservation in Lung Transplantation. Cells. 2021; 10(4):748. Epub 2021/04/04. https:// doi.org/10.3390/cells10040748 PMID: 33805274.

16. Council NR. Guide for the Care and Use of Laboratory Animals: Eighth Edition. Washington, DC: The National Academies Press; 2011. 246 p.

17. Motoyama H, Chen F, Hijiya K, Kondo T, Ohsumi A, Yamada T, et al. Plasmin administration during ex vivo lung perfusion ameliorates lung ischemia-reperfusion injury. J Heart Lung Transplant. 2014; 33 (10):1093-9. Epub 2014/07/22. https://doi.org/10.1016/j.healun.2014.06.004 PMID: 25043623.

18. Halpern SD, Hasz RD, Abt PL. Incidence and distribution of transplantable organs from donors after circulatory determination of death in U.S. intensive care units. Ann Am Thorac Soc. 2013; 10(2):73-80. Epub 2013/04/24. https://doi.org/10.1513/AnnalsATS.201211-1090C PMID: 23607834.

19. Van Raemdonck D, Rega F, Rex S, Neyrinck A. Machine perfusion of thoracic organs. J Thorac Dis. 2018; 10(Suppl 8):S910-S23. Epub 2018/05/11. https://doi.org/10.21037/jtd.2018.02.85 PMID: 29744218; PubMed Central PMCID: PMC5934115.

20. Steen S, Sjoberg T, Pierre L, Liao Q, Eriksson L, Algotsson L. Transplantation of lungs from a nonheart-beating donor. Lancet. 2001; 357(9259):825-9. Epub 2001/03/27. https://doi.org/10.1016/S01406736(00)04195-7 PMID: 11265950.

21. Guibert EE, Petrenko AY, Balaban CL, Somov AY, Rodriguez JV, Fuller BJ. Organ Preservation: Current Concepts and New Strategies for the Next Decade. Transfus Med Hemother. 2011; 38(2):125-42. Epub 2011/05/14. https://doi.org/10.1159/000327033 PMID: 21566713; PubMed Central PMCID: РMС3088735.

22. Luer $B$, Koetting $M$, Efferz $P$, Minor $T$. Role of oxygen during hypothermic machine perfusion preservation of the liver. Transpl Int. 2010; 23(9):944-50. Epub 2010/03/10. https://doi.org/10.1111/j.1432-2277. 2010.01067.x PMID: 20210932.

23. Ben Ali R, Klouz A, Elkadri N, Kourda N, Gaies E, Ben Said D, et al. Effect of liver hypothermic preservation: exploration and protection. Eur Surg Res. 2009; 43(4):348-53. Epub 2009/09/25. https://doi.org/ 10.1159/000241716 PMID: 19776591.

24. Selten J, Schlegel A, de Jonge J, Dutkowski P. Hypo- and normothermic perfusion of the liver: Which way to go? Best Pract Res Clin Gastroenterol. 2017; 31(2):171-9. Epub 2017/06/19. https://doi.org/10. 1016/j.bpg.2017.04.001 PMID: 28624105.

25. Van Caenegem O, Beauloye C, Vercruysse J, Horman S, Bertrand L, Bethuyne N, et al. Hypothermic continuous machine perfusion improves metabolic preservation and functional recovery in heart grafts. Transpl Int. 2015; 28(2):224-31. Epub 2014/10/01. https://doi.org/10.1111/tri.12468 PMID: 25265884.

26. Van Caenegem O, Beauloye C, Bertrand L, Horman S, Lepropre S, Sparavier G, et al. Hypothermic continuous machine perfusion enables preservation of energy charge and functional recovery of heart grafts in an ex vivo model of donation following circulatory death. Eur J Cardiothorac Surg. 2016; 49 (5):1348-53. Epub 2015/11/26. https://doi.org/10.1093/ejcts/ezv409 PMID: 26604296.

27. Hong SB, Koh Y, Lee IC, Kim MJ, Kim WS, Kim DS, et al. Induced hypothermia as a new approach to lung rest for the acutely injured lung. Crit Care Med. 2005; 33(9):2049-55. Epub 2005/09/09. https://doi. org/10.1097/01.ccm.0000178186.37167.53 PMID: 16148479.

28. Le Gal YM, Scott T, Prabhakaran VM, Zhang J, Pushpanathan C, Morrissey L. Heart-lung protection from ischemic injury during 8 hour hypothermic preservation. Acta Biomed Ateneo Parmense. 1994; 65 (3-4):181-98. Epub 1994/01/01. PMID: 7717031.

29. Nakajima D, Chen F, Okita K, Motoyama H, Hijiya K, Ohsumi A, et al. Reconditioning lungs donated after cardiac death using short-term hypothermic machine perfusion. Transplantation. 2012; 94 (10):999-1004. Epub 2012/10/18. https://doi.org/10.1097/TP.0b013e31826f632e PMID: 23073465.

30. Bouma HR, Kroese FG, Kok JW, Talaei F, Boerema AS, Herwig A, et al. Low body temperature governs the decline of circulating lymphocytes during hibernation through sphingosine-1-phosphate. Proc Natl Acad Sci U S A. 2011; 108(5):2052-7. Epub 2011/01/20. https://doi.org/10.1073/pnas.1008823108 PMID: 21245336; PubMed Central PMCID: PMC3033260.

31. Talaei F, Hylkema MN, Bouma HR, Boerema AS, Strijkstra AM, Henning RH, et al. Reversible remodeling of lung tissue during hibernation in the Syrian hamster. J Exp Biol. 2011; 214(Pt 8):1276-82. Epub 2011/03/25. https://doi.org/10.1242/jeb.052704 PMID: 21430204.

32. Quinones QJ, Ma Q, Zhang Z, Barnes BM, Podgoreanu MV. Organ protective mechanisms common to extremes of physiology: a window through hibernation biology. Integr Comp Biol. 2014; 54(3):497-515. Epub 2014/05/23. https://doi.org/10.1093/icb/icu047 PMID: 24848803; PubMed Central PMCID: PMC4184351.

33. Suri LN, Cruz A, Veldhuizen RA, Staples JF, Possmayer F, Orgeig S, et al. Adaptations to hibernation in lung surfactant composition of 13-lined ground squirrels influence surfactant lipid phase segregation 
properties. Biochim Biophys Acta. 2013; 1828(8):1707-14. Epub 2013/03/20. https://doi.org/10.1016/j. bbamem.2013.03.005 PMID: 23506681.

34. Ward LC, Buttery PJ. The patho-physiological basis for tests of viability in isolated perfused organs. Biomedicine. 1979; 30(4):181-6. Epub 1979/10/01. PMID: 534672.

35. Bortner CD, Hughes FM Jr., Cidlowski JA. A primary role for $\mathrm{K}+$ and $\mathrm{Na}+$ efflux in the activation of apoptosis. J Biol Chem. 1997; 272(51):32436-42. Epub 1998/01/24. https://doi.org/10.1074/jbc.272.51. 32436 PMID: 9405453.

36. Koike T, Yeung JC, Cypel M, Rubacha M, Matsuda Y, Sato M, et al. Kinetics of lactate metabolism during acellular normothermic ex vivo lung perfusion. J Heart Lung Transplant. 2011; 30(12):1312-9. Epub 2011/09/21. https://doi.org/10.1016/j.healun.2011.07.014 PMID: 21930395.

37. Couto-Mallon D, Gonzalez-Vilchez F, Almenar-Bonet L, Diaz-Molina B, Segovia-Cubero J, GonzalezCostello J, et al. Prognostic Value of Serum Lactate Levels in Patients Undergoing Urgent Heart Transplant: A Subanalysis of the ASIS-TC Spanish Multicenter Study. Rev Esp Cardiol (Engl Ed). 2019; 72 (3):208-14. Epub 2018/06/04. https://doi.org/10.1016/j.rec.2018.02.021 PMID: 29859897.

38. Machuca TN, Cypel M, Yeung JC, Bonato R, Zamel R, Chen M, et al. Protein expression profiling predicts graft performance in clinical ex vivo lung perfusion. Ann Surg. 2015; 261(3):591-7. Epub 2014/11/ 06. https://doi.org/10.1097/SLA.0000000000000974 PMID: 25371129.

39. Chouchani ET, Pell VR, James AM, Work LM, Saeb-Parsy K, Frezza C, et al. A Unifying Mechanism for Mitochondrial Superoxide Production during Ischemia-Reperfusion Injury. Cell Metab. 2016; 23 (2):254-63. Epub 2016/01/19. https://doi.org/10.1016/j.cmet.2015.12.009 PMID: 26777689.

40. Jassem W, Fuggle SV, Rela M, Koo DD, Heaton ND. The role of mitochondria in ischemia/reperfusion injury. Transplantation. 2002; 73(4):493-9. Epub 2002/03/13. https://doi.org/10.1097/00007890200202270-00001 PMID: 11889418.

41. Honda HM, Korge $P$, Weiss JN. Mitochondria and ischemia/reperfusion injury. Ann N Y Acad Sci. 2005; 1047:248-58. Epub 2005/08/12. https://doi.org/10.1196/annals.1341.022 PMID: 16093501.

42. Rauen $\mathrm{U}$, de Groot $\mathrm{H}$. Mammalian cell injury induced by hypothermia- the emerging role for reactive oxygen species. Biol Chem. 2002; 383(3-4):477-88. Epub 2002/05/30. https://doi.org/10.1515/BC. 2002.050 PMID: 12033437.

43. Muller X, Schlegel A, Kron P, Eshmuminov D, Wurdinger M, Meierhofer D, et al. Novel Real-time Prediction of Liver Graft Function During Hypothermic Oxygenated Machine Perfusion Before Liver Transplantation. Ann Surg. 2019; 270(5):783-90. Epub 2019/10/09. https://doi.org/10.1097/SLA. 0000000000003513 PMID: 31592808.

44. Noda K, Shigemura N, Tanaka Y, Bhama J, D'Cunha J, Kobayashi H, et al. Hydrogen preconditioning during ex vivo lung perfusion improves the quality of lung grafts in rats. Transplantation. 2014; 98 (5):499-506. Epub 2014/08/15. https://doi.org/10.1097/TP.0000000000000254 PMID: 25121557.

45. Dalle-Donne I, Giustarini D, Colombo R, Rossi R, Milzani A. Protein carbonylation in human diseases. Trends Mol Med. 2003; 9(4):169-76. Epub 2003/05/03. https://doi.org/10.1016/s1471-4914(03)000315 PMID: 12727143.

46. Dalle-Donne I, Aldini G, Carini M, Colombo R, Rossi R, Milzani A. Protein carbonylation, cellular dysfunction, and disease progression. J Cell Mol Med. 2006; 10(2):389-406. Epub 2006/06/27. https://doi. org/10.1111/j.1582-4934.2006.tb00407.x PMID: 16796807; PubMed Central PMCID: PMC3933129.

47. NODA K, TANE S, HAAM SJ, D'CUNHA J, HAYANGA AJ, LUKETICH JD, ET AL. TARGETING CIRCULATING LEUKOCYTES AND PYROPTOSIS DURING EX VIVO LUNG PERFUSION IMPROVES LUNG PRESERVATION. TRANSPLANTATION. 2017; 101(12):2841-9. EPUB 2017/04/30. https://doi. org/10.1097/TP.0000000000001798 PMID: 28452921. 